\title{
ГЕНЕТИЧЕСКАЯ ХАРАКТЕРИСТИКА ВИРУСА БОЛЕЗНИ НЬЮКАСЛА СРЕДИ ДИКИХ И ПЕРЕЛЕТНЫХ ПТИЦ В КЫРГЫЗСКОЙ РЕСПУБЛИКЕ
}

R.Z. Nurgaziev, A.R. Nurgazieva

\section{GENETIC CHARACTERIZATION OF NEWCASTLE DISEASE VIRUS AMONG WILD AND MIGRATING BIRDS IN THE KYRGYZ REPUBLIC}

Нургазиев Р.3. - д-р ветеринар. наук, проф., член-корр. Национальной академии наук Кыргызской Республики, ректор Кыргызского национального аграрного университета им. К.И. Скрябина, Кыргызская Республика, г. Бишкек.

E-mail: knau-info@mail.ru

Нургазиева A.P. - канд. биол. наук, зав. лаб. вирусологии и биотехнологии Кыргызского научно-исследовательского института ветеринарии, Кыргызская Республика, г. Бишкек.

E-mail: nurgazieva10@gmail.com

Цель исследования - фрилогенетический анализ изолята болезни Ньюкасла, выделенного на территории Кыргызской Республики от перелетных птиц; анализ роли диких птиц в распространении высоко патогенных вирусов болезни Ньюкасла (БН) на территории Кыргызской Республики, а именно на территории Иссык-кульской области. Болезнь Ньюкасла (псевдочума птиц) - высококонтагиозное заболевание кур и индеек. Симптомы болезни довольно разнообразны. БН может протекать остро, обуславливая иногда гибель всей заболевшей птицы в течение 3-4 дней, и субклинически, что зависит от вирулентности штамма. Вирус болезни Ньюкасла по классифрикации Всемирной организации охраны здоровья животных относится к категории $A$. Был проведен филогенетический анализ выделенного изолята болезни Ньюкасла. Данный изолят был выделен на территории Кыргызской республики среди диких перелетных птии в 2018 г. Выделение вируса болезни Ньюкасла проводили специальным коммерческим набором американского производства Ахуgеп (Аху Prep TM Body Fluid, Viral DNAIRNA miniprepkit). OT-ПЦР проводили с набором Quanti Tect Reverse Transcription Kit Qiagen. Полученные данные были использованы для дальнейших ис-
Nurgaziev R.Z. - Dr. Veterinary Sci., Prof., Corresponding Member, National Academy of Sciences, Kyrgyz Republic, Rector, Kyrgyz National Agricultural University named after K.I. Scriabin, Kyrgyz Republic, Bishkek.

E-mail:knau-info@mail.ru

Nurgazieva A.R. - Cand. Biol. Sci., Head, Lab. of Virology and Biotechnology, Kyrgyz Research Institute of Veterinary Science, Kyrgyz Republic, Bishkek.

E-mail: nurgazieva10@gmail.com

следований по проведению фрилогенетического анализа, идентиффикации и определения штамма вируса. Анализ полной геномной последовательности изолята вируса БН показал, что выделенный изолят относится к генотuny VII класса II. По результатам филогенетического анализа видно, что данный изолят был тесно связан с изолятом Ляонин/02/2005, который был выделен в Китае в 2005 2. Штамм Duck/Kyrgyzstan/2018/kg, наиболее близкий к ранее выделенному от домашних nmuu Chicken/Kyrgyzstan $/ 2015 / \mathrm{kg1}-16$. Выделенный штамм вируса болезни Ньюкасла классифицирован как вирулентный и мезогенный. $B$ этом исследовании штамм вируса болезни Ньюкасла был классифицирован как вирулентный вирус болезни Ньюкасла путем аминокислотного секвенирования расщепления участка белка F. Проведенное исследование показывает на способность одних и тех же вариантов вируса болезни Ньюкасла поражать как домашних, так и диких птии, что может привести к усложнению эпизоотической ситуациu.

Ключевые слова: болезнь Ньюкасла, изолят, штаммы, РГА, ПЦР, реакционная смесь, секвенирование, дикие и перелетные птицы. 
The research objective is phylogenetic analysis of the isolate of Newcastle disease (ND) allocated on the territory of the Kyrgyz Republic from migratory birds; the analysis of the role of wild birds in the distribution of highly pathogenic viruses of Newcastle disease on the territory of the Kyrgyz Republic, namely on the territory of Issyk-kul area. Newcastle disease (pseudotum of birds) is highly contagious disease of hens and turkeys. The symptoms of the disease are quite various. ND can sharply proceed, causing sometimes death of all sick birds within 3-4 days, and subclinically, which depends on the virulence of strain. The virus of Newcastle disease in the classification of the World organization of health protection of animals belongs to category A. Phylogenetic analysis of emitted isolate of Newcastle disease was carried out. This isolate was emitted for territories of the Kyrgyz republic among wild migratory birds in 2018. The allocation of the virus of Newcastle disease was carried out by special commercial set of the American production Axygen (AxyPrepTMBodyFluid, Viral DNAIRNA miniprepkit). PCR was carried out with the Quanti Tect Reverse Transcription Kit Qiagen set. The obtained data were used for further researches on carrying out phylogenetic analysis, the identification and definition of virus strain. The analysis of full genomic sequence of the isolate of virus ND showed that the emitted isolate belonged to class II, genotype VII. By the results of phylogenetic analysis it was visible that this isolate was closely connected with Lyaonin/02/2005 isolate which was emitted in China in 2005. Duck/Kyrgyzstan $/ 2018 / \mathrm{kg}$ strain was the closest to Chicken/Kyrgyzstan/2015/kg1-16 which had been allocated earlier from the poultry. The allocated strain of the virus of Newcastle disease was classified as virulent and mesogene. In the research the strain of the virus of Newcastle disease was classified as a virulent virus of Newcastle disease by amino-acid sequencing of splitting of the site of protein $F$. The conducted research shows the ability of the same options of the virus of Newcastle disease to strike both domestic and wild birds that can lead to complication of epizootic situation.

Keywords: Newcastle disease, isolate, strain, $H A, P C R$, reaction mixture, sequencing, wild and migratory birds.
Введение. Возбудитель болезни Ньюкасла РНК-вирус, относящийся К семейству Paramyxoviridae $[1,2,16,18,20]$. Известно, что из 241 вида семейств птиц 27 отрядов чувствительны к вирусу болезни Ньюкасла [2, 14], например, такие семейства, как Phasianidae, Columbidae, отряд гусеобразные, стрижеобразные, журавлеобразные и другие.

За период 2018 г. по официальным данным Международного эпизоотического бюро болезнь Ньюкасла была зарегистрирована в следующих государствах: Бельгия (2), Болгария (1), Ботсвана (2), Израиль (15), Казахстан (1), Кипр (1), Намибия (13), США (2), Чешская Республика (1), Швеция (1) [7].

В последние годы в Кыргызстане эпизоотии болезни Ньюкасла не наблюдали, возможно, это связано с проводимой вакцинацией домашних птиц. Однако спорадические вспышки заболевания все еще существуют.

Водно-болотные угодья, расположенные в Западной и Центральной Азии, в целом представляют собой основные места зимовки и остановки во время миграции миллионов диких водоплавающих птиц. Ежегодно в Кыргызстан прилетают более 350 видов диких птиц. На зимовку прилетает хохлатая чернеть, гоголь, лоток, зяблик, кряква и другие. По данным Госагентства охраны окружающей среды и лесхоза, в Кыргызстане увеличилась численность редких видов перелетных птиц.

Филогенетический анализ провели для многих штаммов вируса болезни Нюкасла, определены генотипы, всего их 18 [26, 27].

Цель исследований: филогенетический анализ изолята болезни Ньюкасла, выделенного на территории Кыргызской Республики от перелетных птиц; анализ роли диких птиц в распространении высоко патогенных вирусов болезни Ньюкасла на территории Кыргызской Республики, а именно на территории Иссыккульской области.

Материалы и методы исследований. Исследования проводили в Кыргызском научноисследовательском институте ветеринарии им. А. Дуйшеева, в лаборатории вирусологии и биотехнологии.

От птиц в качестве биологического материала для исследований отбирали трахеальные и клоакальные смывы, дополнительно от трупов птиц отбирали кусочки органов (селезенка, легкие, трахея, кишечник, печень) (рис. 1) [17, 21, 22]. 


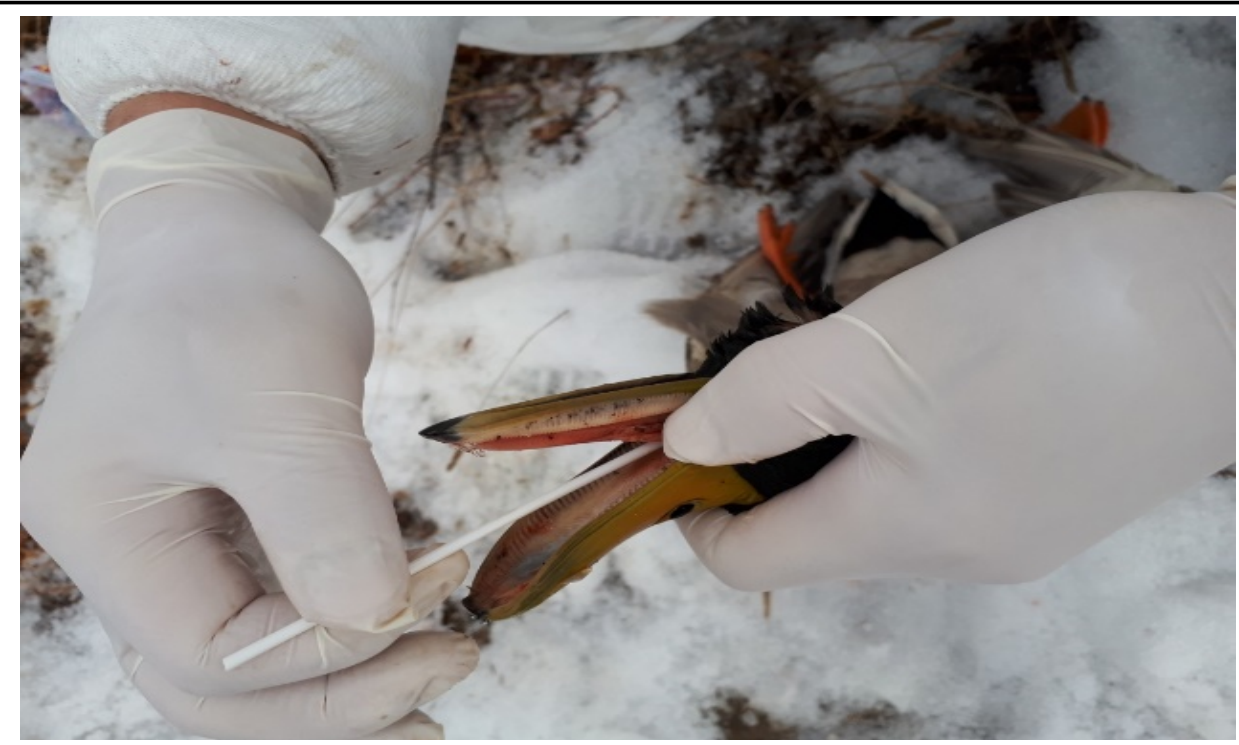

Pис. 1. Трахеальные смывы утки

Куриные эмбрионы 9-11-дневного возраста заражали вирусной суспензией по 0,2 мм в аллантоисную полость. Извлеченную аллантоисную жидкость из куриного эмбриона проверяли с помощью реакции гемагглютинации (РГА) $[7,8,10]$.

Полимеразная цепная реакция. Выделения PHК провели, используя набор «Qia-gen $\mathrm{GmbH}$, согласно инструкции. Использовали праймеры [19] ( $F$ - TCAGAGGGCGGAGAAACAC, R AAAAAGGGCTAATAGGAACAGG) для получения ПЦР продукта. Детекцию ПЦР-продуктов проводили в гель-документирующей системе BioRad.

Нуклеотидное секвенирование и фрилогенетический анализ. Нуклеотидную последовательность продуктов ПЦР получали с использованием набора реакций циклического секвенирования циклов Big Dye Terminator (Applied Biosystems, Foster City, CA) в соответствии с инструкцией производителя с использованием Genetic Analyzer Applied Biosystems 3500 (Life Technologies, Carlsbad, CA). ПЦР-продукты были секвенированы в обоих направлениях. Секвенированные фрагменты генов F и HN были собраны и отредактированы с использованием программного пакета Bio Edit и Finch TV [23, 24].

Результаты исследований и их обсуждение. Штаммы вируса болезни Ньюкасла делятся на велогенные, мезогенные или лентогенные на основе некоторых биологических парамет- ров, таких как MDT (среднее время гибели), секвенирования сайта расщепления F-белка и других методов $[11,12,25,26]$.

Первичным материалом из образцов (легкие, трахеи), полученных от диких перелетных птиц на территории Кыргызской Республики, заражали куриные эмбрионы, в результате выделен изолят вируса болезни Ньюкасла/Duck/Kyrgyzstan/2018/kg. Данный изолят показал высокий титр в реакции гемаглютинации на протяжении двух пассажей.

В наших исследованиях штамм вируса болезни Ньюкасла был классифицирован как вирулентный (путем аминокислотного секвенирования расщепления участка белка F) и мезогенный (путем определения минимальной летальной дозы (ЛМД)).

Анализ полной геномной последовательности изолята вируса пояснил, что этот изолят относится к генотипу VII (рис. 2). В мире на сегодняшний день многие изолированные вирусы болезни Ньюкасла, которые нанесли значительный экономический ущерб домашней птице, попадают под генотип VII [9].

По данным филогенетического анализа видно, что выделенный изолят Duck/Kyrgyzstan/ $2018 / \mathrm{kg}$ тесно связан с изолятом Ляонин 102/2005, который был выделен в Китае в 2005 году (рис. 3). 
- Chicken/China/2011/KC461214

[Chicken/China/2012/KC542914

100

- Duck/China/2014/KP742770

74 -Duck/kyrgyzstan2018/kg

$86 \mathrm{~L}$ Liaoning/02/2005/China/KC542893

Puс. 2. Филогенетический анализ, основанный на полной последовательности генома вируса болезни Ньюкасла среди диких перелетных птиц

Изолят Duck/Kyrgyzstan/2018/kg наиболее близкий к ранее выделенному штамму от домашних птиц в 2015Kg-1/16 [27]. В Кыргызской Республике были выявлены изоляты от домашних птиц во время вспышек болезни Ньюкасла в
Кыргызстане 2005 г. Это указывает на способность вируса болезни Ньюкасла поражать домашних и диких птиц. Нельзя недооценивать роль диких птиц в распространении высокопатогенных вирусов болезни Ньюкасла.

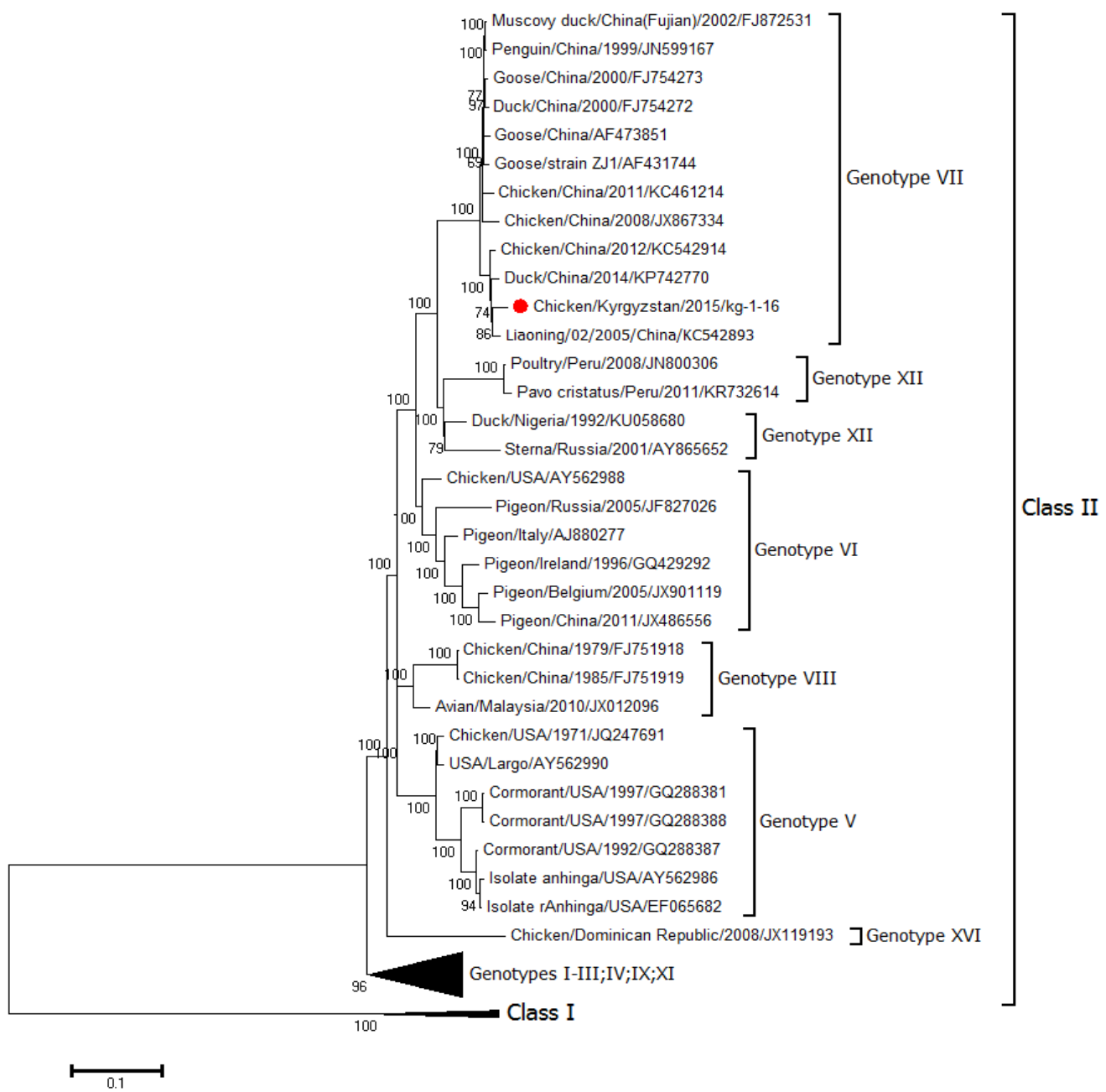

Puc. 3. Филогенетический анализ, основанньй на полной последовательности генома вируса болезни Ньюкасла класса I и II, доступный в GenBank (положение штамма Kg-1/16 на дереве показано красной точкой) 


\section{Выводы}

1. По данным филогенетического анализа выделен изолят Duck $/ K y r g y z s t a n / 2018 / \mathrm{kg}$. Данный изолят тесно связан с изолятом Ляонин/ 02/2005, который был выделен в Китае в 2005 г.

2. Штамм Duck/Kyrgyzstan $/ 2018 / \mathrm{kg}$ наиболее близок к ранее выделенному от домашних птиц Chicken/Kyrgyzstan/2015/kg1-16.

3. Выделенный штамм вируса болезни Ньюкасла классифицирован как вирулентный и мезогенный. В этом исследовании штамм вируса болезни Ньюкасла был классифицирован как вирулентный вирус болезни Ньюкасла путем аминокислотного секвенирования расщепления участка белка $\mathrm{F}$.

4. Проведенные исследования показывают на способность одних и тех же вариантов вируса болезни Ньюкасла поражать как домашних, так и диких птиц, что может привести к усложнению эпизоотической ситуации.

\section{Литература}

1. Сюрин В.Н., Самуйленко А.Я., Соловьев Б.В., Фомина Н.В. Вирусные болезни животных. - М., 1998.

2. Bogoyavlenskiy A., Berezin V., Prilipov A. et al., 2009. Newcastle disease outbreaks in Kazakhstan and Kyrgyzstan during 1998(2000), 2001, 2003.2004, and 2005 were caused by viruses of the genotypes VIllb and VIId. Virus Genes 39, 94-101.

3. Alexander D.J. Newcastle disease virus and other avian para- myxoviruses // Swayne D.E., Glisson J.R., Jackwood M.W., Pearson J.E., Reed W.M. (eds) A laboratory manual for the isolation, identification, and characterization of avian pathogens, 4th edn. American Association of Avian Pathologists, Athens, 1998. - pp. 156-163.

4. Lancaster D.J. The control of Newcastle Disease / Zootechnica international. - 1982. № 6. - P. 16-27.

5. Орынбаев М.Б., Султанкулова К.Т., Керимбаев А.А. и др. Молекулярнобиологические свойства патогенных вирусов болезни Ньюкасла, выделенных на территории Казахстана // Сельскохозяйственная биология. - 2016. - Т. 51, вып. 2. C. 255-263.

6. Alexander D.J., Senne D.A. Avian paramyxoviruses 2-9 // Y.M. Saif, A.M. Fadly, J.R. Glisson, L.R. McDougald, L.K. Nolan, D.E. Swayne (eds) Diseases of poultry, 12th edn. Wiley-Blackwell, Hoboken, 2008. pp. 75-116.

7. O.I.E. World Organisation for Animal Health (2012) Manual of diagnostic tests and vaccines for terrestrial animals: mammals, birds and bees. Biological Standards Commission, World Organization for Animal Health, Paris, pp. 1-19.

8. Nidzworski D., Wasilewska E., Smietanka K., Szewczyk B., Minta Z. Detection and differentiation of Newcastle disease virus and influenza virus by using duplex real-time PCR. ActaBiochim 2013. Pol 60:475-480.

9. Bogoyavlenskiy A., Berezin V., Prilipov A. Newcastle disease outbreaks in Kazakhstan and Kyrgyzstan during 1998 (2000), 2001, 2003,2004 , and 2005 were caused by viruses of the genotypes VIIb and VIId. Virus Genes 39:2009.94-101.

10. Chen S., Hao H., Liu Q. et al. Phylogenetic and pathogenic analyses of two virulent Newcastle disease viruses isolated from Crested Ibis (Nipponianippon) in China. 2013. Virus Genes 46:447-453.

11. Liu X.F., Wan H.Q., Ni X.X., Wu Y.T., Liu W.B. Pathotypical and genotypical characterization of strains of Newcastle disease virus isolated from outbreaks in chicken and goose flocks in some regions of China during 1985-2001. Arch Virol2003. 148:1387-1403.

12. Camila C. Fernandes Molecular and phylogenetic characterization based on the complete genome of a virulent pathotype of Newcastle disease virus isolated in the 1970s in Brazil [2014].

13. Kydyrmanov A., Sayatov M., Karamendin K. et al. Monitoring of influenza A viruses in wild bird populations in Kazakhstan in 2002-2009. 2017. Arch Virol 162:147-155. 
14. Alexander D.J. Newcastle disease and other avian paramyxoviruses Rev Sci Tech, 2000, no. 19(2), pp. 443-62.

15. Aldous E.W., Mynn J.K., Banks J., Alexander D.J. A molecular epidemiological study of avian paramyxovirus type 1 (Newcastle disease virus) isolates by phylogenetic analysis of a partial nucleotide sequence of the fusion protein gene. Avian Pathol, 2003, no. 32, pp. 239-256.

16. Болезни домашних и сельскохозяйственных птиц: пер. с англ. / под ред. Б.У. Келнека, Х.Дж. Барнса, Ч.У. Биэрда, Л.Р. Макдугалда [и др.]. - М.: АКВАРИУМ БУК, 2003. - 1232 c.

17. Cattoli G., Manvell R.I., Tisato E. Characterization of Newcastle disease viruses isolated in Italy in 2000 // Avian. Pathol. - 2001. V. 30. - P. 465-469.

18. Alexander D.J. Newcastle disease in countries of the European Union // Avian Pathol. 1995. - V. 24. - P. 3-10.

19. Vienna R. Brown, Sarah N. Bevins. A review of virulent Newcastle disease viruses in the United States and the role of wild birds in viral persistence and spread // Veterinary Research. - 2017. - № 48.

20. Инфекционные болезни животных: учебник / под ред. А.А. Сидорчука, Н.А. Масимов, В.Л. Крупальник [и др.]. - 2-е изд., перераб. и доп. - М.: ИНФРА-М, 2016. - 954 с.

21. Dwi Desmiyeni Putri, Ekowati Handharyani, Retno Damajanti Soejoedono, Agus Setiyono, Ni Luh Putu Ika Mayasari, Okti Nadia Poetri. Pathotypic characterization of Newcastle disease virus isolated from vaccinated chicken in West Java, Indonesia. Vet World. 2017 Apr; 10(4): 438-444.

22. Cattoli G., Fusaro A., Monne I. et al. Emergence of a new genetic lineage of Newcastle disease virus in West and Central Africaimplications for diagnosis and control. 2010Vet Microbiol 142:168-176.

23. Al-Habeeb M.A., Mohamed M.H.A., Sharawi $S$. Detection and characterization of Newcastle disease virus in clinical samples using real time RT-PCR and melting curve analysis based on matrix and fusion genes amplification. 2013. Vetworld 6:239-243.

24. Sabra M., Dimitrov K.M., Goraichuk I.V. et al. Phylogenetic assessment reveals continuous evolution and circulation of pigeon-derived virulent avian avulaviruses 1 in Eastern Europe, Asia, and Africa. 2017 BMC Vet Res. 13:291.

25. Daulbaeva K.D., Asanova S.E., Butakova I.Sh. i dr. Harakter istikaparamiksovirusov serotipa 1, vydelennyh na territorii Respubliki Kazahstan // Sovr. metodybor'by $\mathrm{s}$ boleznjamizhivotnyh v Kazahstane. Almaty, 1993, pp.53-58.

26. Diel D.G., Silva L.H.A., Liu H., Wang Z., Miller P.J., Afonso C.L. Genetic diversity of avian paramyxovirus type 1: Proposal for a unified nomenclature and classification system of Newcastle disease virus genotypes. Infect. Genet. Evol., 2012, 12: 1770-1779 (doi:10.1016/j.meegid.2012.07.012).

27. Courtney S.C., Susta L., Gomez D., Hines N.L., Pedersen J.C., Brown C.C., Millr P.J., Afonso C.L. Highly divergent virulent isolates of Newcastle disease virus from the Dominican Republic are members of a new genotype that may have evolved unnoticed forover 2 decades. J. Clin. Microbiol., 2013, 51: 508-517 (doi: 10.1128/JCM.0239312).

\section{Literatura}

1. Syurin V.N., Samujlenko A.YA., Solov'ev B.V., Fomina N.V. Virusnye bolezni zhivotnyh. - M., 1998.

2. Bogoyavlenskiy A., Berezin V., Prilipov A. et al., 2009. Newcastle disease outbreaks in Kazakhstan and Kyrgyzstan during 1998(2000), 2001, 2003.2004, and 2005 were caused by viruses of the genotypes VIIb and VIId. Virus Genes 39, 94-101.

3. Alexander D.J. Newcastle disease virus and other avian para- myxoviruses // Swayne D.E., Glisson J.R., Jackwood M.W., Pearson J.E., Reed W.M. (eds) A laboratory manual 
for the isolation, identification, and characterization of avian pathogens, 4th edn. American Association of Avian Pathologists, Athens, 1998. - pp. 156-163.

4. Lancaster D.J. The control of Newcastle Disease / Zootechnica international. - 1982. № 6. - P. 16-27.

5. Orynbaev M.B., Sultankulova K.T., Kerimbaev A.A. i dr. Molekulyarnobiologicheskie svojstva patogennyh virusov bolezni N'yukasla, vydelennyh na territorii Kazahstana I/ Sel'skohozyajstvennaya biologiya. - 2016. - T. 51, vyp. 2. - S. 255263.

6. Alexander D.J., Senne D.A. Avianparamyxoviruses 2-9 // Saif Y.M., Fadly A.M., Glisson J.R., McDougald L.R., Nolan L.K., Swayne D.E. (eds) Diseases of poultry, 12th edn. Wiley-Blackwell, Hoboken, 2008. pp. 75-116.

7. O.I.E. World Organisation for Animal Health (2012) Manual of diagnostic tests and vaccines for terrestrial animals: mammals, birds and bees. Biological Standards Commission, World Organization for Animal Health, Paris, pp. 1-19.

8. Nidzworski D., Wasilewska E., Smietanka K., Szewczyk B., Minta Z. Detection and differentiation of Newcastle disease virus and influenza virus by using duplex real-time PCR. ActaBiochim 2013. Pol 60:475-480.

9. Bogoyavlenskiy A., Berezin V., Prilipov A. Newcastle disease outbreaks in Kazakhstan and Kyrgyzstan during 1998 (2000), 2001, 2003, 2004, and 2005 were caused by viruses of the genotypes VIlb and VIld. Virus Genes 39:2009.94-101.

10. Chen S., Hao H., Liu Q. et al. Phylogenetic and pathogenic analyses of two virulent Newcastle disease viruses isolated from Crested Ibis (Nipponianippon) in China. 2013. Virus Genes 46:447-453.

11. Liu X.F., Wan H.Q., Ni X.X., Wu Y.T., Liu W.B. Pathotypical and genotypical characterization of strains of Newcastle disease virus isolated from outbreaks in chicken and goose flocks in some regions of China during 1985-2001. Arch Virol2003. 148:1387-1403.

12. Camila $C$. Fernandes Molecular and phylogenetic characterization based on the complete genome of a virulent pathotype of Newcastle disease virus isolated in the 1970s in Brazil [2014].

13. Kydyrmanov A., Sayatov M., Karamendin K. et al. Monitoring of influenza A viruses in wild bird populations in Kazakhstan in 2002-2009. 2017. Arch Virol 162:147-155.

14. Alexander D.J. Newcastle disease and other avian paramyxoviruses Rev Sci Tech, 2000, no. 19(2), rr. 443-62.

15. Aldous E.W., Mynn J.K., Banks J., Alexander D.J. A molecular epidemiological study of avian paramyxovirus type 1 (Newcastle disease virus) isolates by phylogenetic analysis of a partial nucleotide sequence of the fusion protein gene. Avian Pathol, 2003, no. 32, pp. 239-256.

16. Bolezni domashnih i sel'skohozyajstvennyh ptic: per. s angl. I pod red. B.U. Kelneka, H.Dzh. Barnsa, CH.U. Bierda, L.R. Makdugalda [i dr.]. - M.: AKVARIUM BUK, 2003. - $1232 \mathrm{~s}$.

17. Cattoli G., Manvell R.I., Tisato E. Characterization of Newcastle disease viruses isolated in Italy in 2000 // Avian. Pathol. - 2001. - V. 30. - P. 465-469.

18. Alexander D.J. Newcastle disease in countries of the European Union // Avian Pathol. 1995. - V. 24. - P. 3-10.

19. Vienna R. Brown, Sarah N. Bevins. A review of virulent Newcastle disease viruses in the United States and the role of wild birds in viral persistence and spread // Veterinary Research. - 2017. - № 48.

20. Infekcionnye bolezni zhivotnyh: uchebnik / pod red. A.A. Sidorchuka, N.A. Masimov, V.L. Krupal'nik [i dr.]. - 2-e izd., pererab. i dop. M.: INFRA-M, 2016. - $954 \mathrm{~s}$.

21. Dwi Desmiyeni Putri, Ekowati Handharyani, Retno Damajanti Soejoedono, Agus Setiyono, Ni Luh Putu Ika Mayasari, Okti Nadia Poetri. Pathotypic characterization of Newcastle dis- 
ease virus isolated from vaccinated chicken in West Java, Indonesia. Vet World. 2017 Apr; 10(4): 438-444.

22. Cattoli G., Fusaro A., Monne I. et al. Emergence of a new genetic lineage of Newcastle disease virus in West and Central Africaimplications for diagnosis and control. 2010Vet Microbiol 142:168-176.

23. Al-Habeeb M.A., Mohamed M.H.A., Sharawi $S$. Detection and characterization of Newcastle disease virus in clinical samples using real time RT-PCR and melting curve analysis based on matrix and fusion genes amplification. 2013. Vetworld 6:239-243.

24. Sabra M., Dimitrov K.M., Goraichuk I.V. et al. Phylogenetic assessment reveals continuous evolution and circulation of pigeon-derived virulent avian avulaviruses 1 in Eastern Europe, Asia, and Africa. 2017 BMC Vet Res. 13:291.
25. Daulbaeva K.D., Asanova S.E., Butakova I.Sh. i dr. Harakter istikaparamiksovirusov serotipa 1, vydelennyh na territorii Respubliki Kazahstan // Sovr. metodybor'by s boleznjamizhivotnyh v Kazahstane. Almaty, 1993, rr.53-58.

26. Diel D.G., Silva L.H.A., Liu H., Wang Z., Miller P.J., Afonso C.L. Genetic diversity of avian paramyxovirus type 1: Proposal for a unified nomenclature and classification system of Newcastle disease virus genotypes. Infect. Genet. Evol., 2012, 12: 1770-1779 (doi:10.1016/j.meegid.2012.07.012).

27. Courtney S.C., Susta L., Gomez D., Hines N.L., Pedersen J.C., Brown C.C., Millr P.J., Afonso C.L. Highly divergent virulent isolates of Newcastle disease virus from the Dominican Republic are members of a new genotype that may have evolved unnoticed forover 2 decades. J. Clin. Microbiol., 2013, 51: 508-517 (doi: 10.1128/JCM.02393-12). 